\title{
Four Times Yearly
}

National Cancer Institute

\section{Source}

National Cancer Institute. Four Times Yearly. NCI Thesaurus. Code C98853.

Four times per year. 